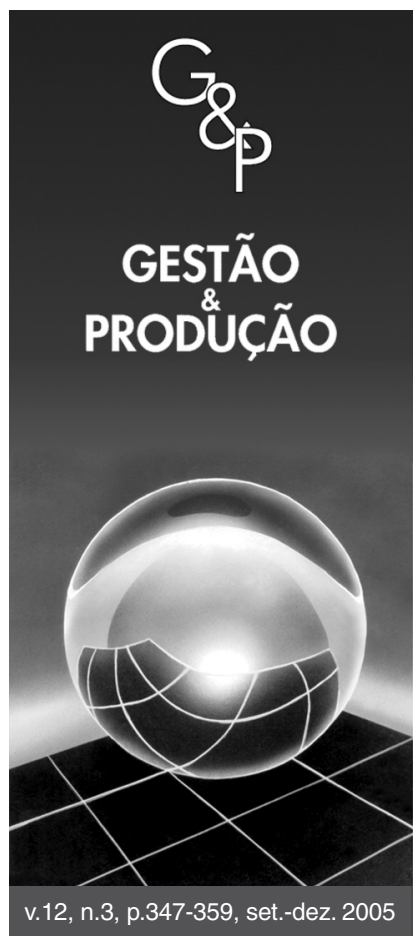

\title{
EFFECTS OF TECHNOLOGY ADOPTION ON MASS CUSTOMIZATION ABILITY OF BROAD AND NARROW MARKET FIRMS
}

\author{
Giovani José Caetano da Silveira \\ Haskayne School of Business, University of Calgary, \\ 2500 University Drive NW, Calgary, Alberta T2N 1N4, Canada, \\ e-mail: giovani.dasilveira@ haskayne.ucalgary.ca \\ Flávio Sanson Fogliatto \\ Departamento de Engenharia de Produção e Transportes, \\ Universidade Federal do Rio Grande do Sul, \\ Praça Argentina 9/402, CEP 90040-020, Porto Alegre, RS, Brasil, \\ e-mail: ffogliatto@ppgep.ufrgs.br
}

Abstract

Recebido em 28/6/2005

Aceito em 28/10/2005

Despite the increasing number of mass customization $(M C)$ studies in the literature and practice, two research gaps still remain. First, there is a lack of empirical studies to test predicted theoretical relationships between MC strategic, technical, and performance aspects (Tu et al., 2001). Second, there is limited understanding about the role of technology, including information technology in MC systems (Åhlström and Westbrook, 1999). This paper investigates the effects of technology adoption on the MC ability of 315 manufacturers of metal products, machinery, and equipment with either narrow or broad strategic market scope. The results suggest that different technologies have different effects on the MC dimensions of product capability and productivity, and that this effect is determined by the market scope of the firm.

Keywords: mass customization, technology, marketing/operations interface.

\section{Introduction}

Over the last decade mass customization (MC) has evolved from being a visionary concept (Davis, 1987) to becoming a valuable business strategy. A growing number of firms in various industrial sectors have been applying advanced manufacturing and information technologies to mass produce low-cost personalized products (Duray, 2002). Well-known examples of mass customized products include diesel engines, bicycles, computers, insurance, fast-food, footwear, apparel, and pagers (da Silveira et al., 2001). These products have been designed and produced in a way to meet the unique needs of customers at a reasonable price (Pine, 1993).

Research in MC has also evolved in the last decade. Studies in the early 1990s were mainly focused on the MC concept and its implications for manufacturing and service industries (e.g. Boynton et al., 1993; Westbrook and Williamson, 1993; Hart, 1995; Kotha, 1995). Empirical evidence was mainly provided by paradigmatic cases such as the National Industrial Bicycle Company of Japan (Kotha, 1996), Motorola (Eastwood, 1996), and Hewlett-Packard (Feitzinger and Lee, 1997). Those studies provided the foundations for contemporary research having emphasis on applied, implementation-related issues in MC such as assessment of customer preferences (e.g. Liechty et al., 2001; Fiore et al., 2004) and manufacturing suitability to MC (Fogliatto et al., 2003), product characterization (e.g. Chan and Cheung, 2001) and design (McMains, 2005), and the analysis of product commonality (e.g. Jiao and Tseng, 2000) and modularity (Tu et al., 2004).

However, at least two major research gaps still remain in the MC literature. The first concerns the lack of empirical studies investigating the relationships between MC strategic, technical, and performance aspects (as pointed out by Tu et al., 2001). It is fair to say that most of the concepts proposed in early MC studies have not yet been 
validated by empirical testing. The second gap concerns the lack of understanding about the role of technology, including information technology, in MC systems (Åhlström and Westbrook, 1999). The current literature (e.g. Byrd, 2001; Gros, 2001; Xiao et al., 2001) seems to focus more on the potential capabilities provided by advanced technologies than on the actual effects of technology adoption on the organization and performance of MC producers.

This article addresses the two gaps outlined above. We investigate the effect of technology adoption on the MC ability of manufacturing firms with broad and narrow market scope. We focus on three major technologies that have been associated to MC: Computerized Numerical Control (CNC), Flexible Manufacturing Systems (FMS), and Internet application to sales and customer relationship management (McDermott et al., 1997; da Silveira et al., 2001; Zipkin, 2001). Market scope is defined by the variety of markets and customers served by the business unit. Improvement in MC ability may be assessed by changes in the degree of product customization and in productivity levels, which are the two performance dimensions of MC. In this paper we test the relationships between market scope, technology adoption, and MC through empirical analysis of 315 manufacturers of fabricated metal products, machinery, and equipment from 14 countries.

\section{Background}

Mass customization (MC) is the ability to produce customized products on a large scale at low-cost (Boynton et al., 1993; Pine, 1993; da Silveira et al., 2001; Broekhuizen et Alsem, 2002). This concept implies that an organization's MC ability may be determined by three elements (Tu et al., 2001). First, operations must be able to produce differentiated products to meet the requirements of individual customers. Second, the cost of MC products must be close to that of mass-produced items. Third, economical feasibility implies large scale production and, consequently, access to a broad range of markets and customers. Hence, MC consists in overcoming the traditional cost-variety trade-off in operations (Kotha, 1995; Mann and Domb, 2001; Prabhacker, 2001) while operating in a mass market context (Zipkin, 2001): the paradox of making low cost, personalized products in a high volume production environment (Duray, 2002).

Authors such as Pine (1993), Kotha (1995), and Hart (1995) suggested that MC emerged as an industrial phenomenon due to three major elements. First, shorter product life cycles and increasing global competition led to a breakdown in mass markets, increasing operations strategic focus on individual customers. Second, customers started demanding greater levels of variety and personalization in products and services. Third, flexible manufac- turing and information technologies enabled producers to deliver customized products at low cost. There is growing consensus in the literature (e.g. Fürst and Schmidt, 2001; Zipkin, 2001) that MC strategies are only viable in a market context where personalization is demanded and in an industrial context where technology is available.

The requirements above help to visualize why successful MC has been mainly found in specific markets and industries. Most of the literature has been focused on traditional manufacturing sectors such as metal-mechanic, electronics, and apparel. Well-known examples include the National Bicycle Industrial Company of Japan (Westbrook and Williamson, 1993; Kotha, 1995), Ross Controls (Pine et al., 1995; Karnes and Karnes, 2000; Byrd, 2001), Motorola (Hart, 1995; Eastwood, 1996; Lau, 1996), and Levi Strauss (Hart, 1996; Norman and Thisse, 1999; Zipkin, 2001). Likewise, most empirical MC studies (e.g. Duray et al., 2000; Tu et al., 2001) have targeted industrial sectors such as fabricated metal products, machinery, electrical, and transportation equipment. Recent Brazilian studies have also focused on sectors including telecommunications, energy, and online retail (Quintella and Silva, 2003; Quintella et al., 2005a; Quintella et al., 2005b).

As discussed above, flexible manufacturing and information technologies have long been credited as major enablers of MC. Even though studies emphasized the role of other elements such as lean operations and time-based manufacturing practices (Taylor and Lyon, 1995; Jina et al., 1997; Tu et al., 2001), it is widely accepted that advanced manufacturing and information technologies provide the basic means to overcome the cost-variety trade-off which is the key for a successful MC implementation (Kotha, 1995; Duray et al., 2000; Zipkin, 2001). Major MC technologies include Computerized Numerical Control (CNC), Flexible Manufacturing Systems (FMS), and Internet application to sales and customer relationship management (McDermott et al., 1997; da Silveira et al., 2001; Zipkin, 2001).

CNC technology provides two essential MC capabilities. First, it helps to turn complex, innovative designs quickly into products. Pine et al. (1995) provided the example of Ross Controls that was able to electronically transmit tooling instructions from engineering workstations to $\mathrm{CNC}$ equipment, which manufactured new designs in lead times as short as a day. Such a process was facilitated by a practice of translating manufacturing specifications into $\mathrm{CNC}$ instructions as soon as customers placed orders for personalized products. Second, $\mathrm{CNC}$ provides the ability to reconfigure machines with little downtime (McDermott et al., 1997; Keltner et al., 1999). This allows for economies of scale even in a context of customized, small batch production. 
FMS has the potential to simultaneously improve manufacturing productivity and flexibility, reducing the costs of customization (Jaikumar, 1986; Norman and Thisse, 1999). It allowed firms such as Levi Strauss and Custom Foot to customize their products (respectively women's jeans and shoes) at little or no cost penalty (Norman and Thisse, 1999). As explained by Lau (1996), an FMS can manufacture assorted products using machines linked by automated materials handling systems and a computer system. Preprogrammed, integrated workstations can produce a family of parts whenever needed. Lau (1996) provided the examples of General Electric and Motorola which used FMS to produce custom-made circuit boxes and electronic pagers in a short time.

Finally, Internet is increasingly being used as the main channel to provide customers with information on product customization choices (Liechty et al., 2001). The best known case example in the literature seems to be that of Dell Computers, which provides a Web channel for customers to personalize computers from a selection of components, features, and software (Byrd, 2001; Crosby and Johnson, 2002). In general, web-based choice menus provide the means by which customers become aware of the different features and options available for configuring personalized products and services (Liechty et al., 2001). In addition, customers may use the website after purchasing to track orders and make use of service and support (Kagan et al., 2000).

The literature review provides three major ideas about MC, which are summarized in our research model (Figure 1). First, MC involves two performance dimensions that are productivity and customization ability; for a MC strategy to be economically feasible, providers should build competitiveness on the two dimensions simultaneously. Second, technology is the major enabler to overcome that cost-variety trade-off; adopting advanced manufacturing and information technologies such as CNC, FMS, and Internet will potentially lead to simultaneous

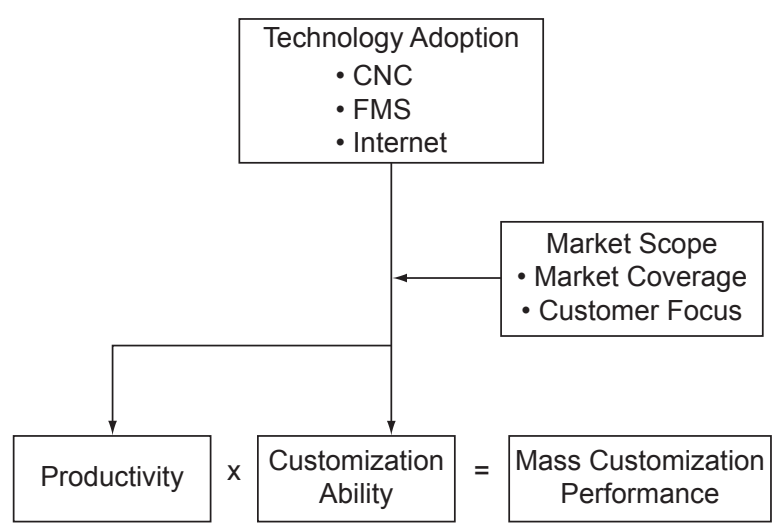

Figure 1. Research model. improvements in the two MC performance dimensions. Third, to be economically sustainable, MC strategies usually require the access to a broad, diversified range of markets and customers; hence, the actual effect of technology adoption on productivity and customization performance will be moderated by the market scope of the firm. To test those relationships, we formulated the following research hypothesis:

Hypothesis 1 . Technology adoption is more positively related to mass customization ability when the manufacturing firm has a broad market scope than when the manufacturing firm has a narrow market scope.

\section{Methods}

\subsection{Sample}

This research used data from the 2000 edition of the International Manufacturing Strategy Survey (IMSS-III). IMSS has been designed to identify the strategies, practices, and performance of manufacturing firms around the world. The survey has been carried out since 1992 by an international network of manufacturing strategy researchers. Data from previous IMSS rounds have been used in several manufacturing strategy studies such as Voss and Blackmon (1998), Cagliano and Spina (2000), and Frohlich and Westbrook (2001).

The 2000 edition included responses from 14 countries. Survey companies were in ISIC Division 38, Manufacture of Fabricated Metal Products, Machinery, and Equipment. The survey focuses on that division because of its large presence worldwide and pioneering role in implementing operations management methods and technologies. A focus on metal-mechanic and equipment manufacturers was especially useful to our research, since those sectors are the most commonly discussed in MC conceptual and empirical studies (see Duray et al., 2000, and Tu et al., 2001, among others).

Data collection was administered in a country-bycountry basis by local research coordinators. Wherever necessary, the original questionnaire in English was translated by manufacturing strategy academics. Questionnaires were mailed or e-mailed to the Director of Operations/Manufacturing or the person with the equivalent position in the company. An attached letter explained the purpose of IMSS, the structure of the questionnaire, and assurances of confidentiality. Follow-up letters, faxes, emails and calls helped to achieve a response rate close to 20\% (Dillman, 1978). Questionnaires were returned by mail or fax to the country office. Researchers in each country processed data from questionnaires into spreadsheets, which were consolidated at Politecnico di Milano, Italy. The consolidated database was released to the network in July 2002. 
The July 2002 release included 474 manufacturers, 315 of which had usable responses for the purposes of this study (Table 1). ANOVA tests did not show significant differences between the IMSS sample and the study sample with respect to size, production process, or process layout (Table 2). The ANOVA indicates that unused responses may be viewed as a random sample of the complete population of respondents; therefore, ignoring such responses did not bias the conclusions from statistical analyses to follow.

\subsection{Measures}

Moderating variables. We grouped sample companies based on the two market scope variables of market coverage and customer focus. Companies described

Table 1. Sample composition $(n=315)$.

\begin{tabular}{lrr}
\hline \multicolumn{1}{c}{ Country of Origin } & n & \% \\
\hline Argentina & 10 & 3.2 \\
Australia & 30 & 9.5 \\
Belgium & 14 & 4.4 \\
China & 10 & 3.2 \\
Denmark & 30 & 9.5 \\
Germany & 22 & 7.0 \\
Hungary & 39 & 12.4 \\
Ireland & 21 & 6.7 \\
Italy & 52 & 16.5 \\
Netherlands & 7 & 2.2 \\
Norway & 18 & 5.7 \\
Spain & 13 & 4.1 \\
Sweden & 15 & 4.8 \\
United Kingdom & 34 & 10.8 \\
\hline & $\mathbf{n}$ & $\%$ \\
381 Metal products & 93 & 29.5 \\
382 Machinery & 103 & 32.7 \\
383 Electrical equipment & 64 & 20.3 \\
384 Transportation equipment & 30 & 9.5 \\
385 Scientific equipment & 25 & 7.9 \\
\hline
\end{tabular}

the market aims of their business units using five-point scales. Market coverage was measured using a scale ranging from "few markets" (1) to "many markets" (5). Customer focus was measured using a scale ranging from "few customers" (1) to "many customers" (5).

A hierarchical cluster analysis of subjects was carried out based on the two moderating variables. Ward's method was used to minimize within cluster variances (Rencher, 1995); the squared Euclidean distance measure, which is the recommended distance measure for Ward's method, was also applied (Hair et al., 1998: 486). Companies were classified into two clusters. Cluster 1 $(\mathbf{n}=200)$ included companies with narrow market coverage (mean $=2.69$, s.d. $=.93$ ) and narrow customer focus $($ mean $=2.85$, s.d. $=.98)$. Group $2(\mathbf{n}=115)$ included companies with broad market coverage $($ mean $=4.42$, s.d. $=.63$ ) and broad customer focus (mean $=4.47$, s.d. $=.61$ ). Complete results are presented in Table 3. The null hypotheses that clusters had equal market coverage or equal customer focus were rejected ( $p$-value $<.001$ in both cases). Following the rationale in Punj and Stewart (1983), we used a non-hierarchical cluster analysis to test the stability of the solution obtained using Ward's method. Ward's means were used as cluster seeds to the $K$-means (Quick Cluster) procedure in SPSS 11.0. Results from both analyses were identical, with no subject reassigned to a different cluster. The resulting groups were used as the sub-samples in our regression models.

Dependent variables. The trade-off between product personalization (or versatility) and productivity (or cost) is inherent to the MC concept (Mann and Domb, 2001). Therefore we used three dependent variables in this study. Two primary variables accounted for changes in product customization ability and labor productivity; they are the main factors in the regression model. One secondary variable accounted for changes in mass customization ability, and was given by the interaction between the two primary variables. Changes in product customization ability and labor productivity were assessed by the following question: "Please indicate the amount of change of

Table 2. Differences between used and unused responses*.

\begin{tabular}{lccc}
\hline & IMSS Sample & Study Sample & \multicolumn{1}{c}{$\boldsymbol{p}$} \\
\hline Size (number of employees) & $903.90(474)$ & $828.04(315)$ & \\
Production Process (\% of value added) & & & \\
Fabrication & $55.69(455)$ & $54.13(312)$ & .516 \\
Assembly & $44.31(455)$ & $45.87(312)$ & .516 \\
Process Layout (\% of total volume) & & & \\
Job shop & $37.26(452)$ & $38.01(315)$ & .788 \\
Cellular manufacturing & $30.31(452)$ & $29.71(315)$ & .801 \\
Dedicated lines & $32.43(452)$ & $32.28(315)$ & .955 \\
\hline
\end{tabular}

* Sample sizes are in brackets; cases with missing data were excluded analysis-by-analysis. 
Table 3. Results of ANOVA between Clusters*.

\begin{tabular}{|c|c|c|c|c|c|c|c|}
\hline \multirow[b]{2}{*}{ Variable } & \multicolumn{2}{|c|}{$\begin{array}{c}\text { Group 1: Narrow } \\
\text { Market Coverage and } \\
\text { Customer Focus } \\
n=200\end{array}$} & \multicolumn{2}{|c|}{$\begin{array}{c}\text { Group 2: Broad } \\
\text { Market Coverage and } \\
\text { Customer Focus } \\
n=115\end{array}$} & \multicolumn{2}{|c|}{$\begin{array}{c}\text { Total Sample } \\
n=315\end{array}$} & \multirow[b]{2}{*}{$F$ value } \\
\hline & mean & s.d. & mean & s.d. & mean & s.d. & \\
\hline \multicolumn{8}{|l|}{ Moderating } \\
\hline 1. Market coverage & 2.69 & .93 & 4.42 & .63 & 3.32 & 1.18 & $314.63 * * *$ \\
\hline 2. Customer focus & 2.85 & .98 & 4.47 & .61 & 3.44 & 1.16 & $259.05 * * *$ \\
\hline \multicolumn{8}{|l|}{ Dependent } \\
\hline 3. Product custom. & 3.50 & .74 & 3.60 & .77 & 3.54 & .75 & 1.30 \\
\hline 4. Labor productivity & 3.57 & .72 & 3.60 & .69 & 3.58 & .71 & 0.18 \\
\hline \multicolumn{8}{|l|}{ Independent } \\
\hline 5. $\mathrm{CNC}$ & 2.60 & 1.25 & 2.80 & 1.22 & 2.67 & 1.24 & 2.00 \\
\hline 6. FMS & 1.73 & .62 & 1.92 & .78 & 1.80 & .69 & $5.85 * *$ \\
\hline 7. Internet & 1.86 & .93 & 2.08 & 1.12 & 1.94 & 1.01 & 3.75 \\
\hline \multicolumn{8}{|l|}{ Control } \\
\hline 8. Size & 564.16 & 1332.09 & 1286.97 & 5963.69 & 828.04 & 3762.76 & 2.71 \\
\hline 9. End user sales & 32.24 & 38.66 & 35.11 & 38.99 & 33.29 & 38.74 & .40 \\
\hline 10. Market growth & 3.27 & .90 & 3.45 & .73 & 3.33 & .84 & 3.62 \\
\hline 11. Cellular manufac. & 29.45 & 31.77 & 30.17 & 32.95 & 29.71 & 32.16 & .04 \\
\hline 12. Multi-skilled labor & 52.36 & 29.79 & 50.31 & 28.13 & 51.61 & 29.17 & .36 \\
\hline
\end{tabular}

the following performance dimensions over the last three years". Respondents used a five-point scale ranging from "strongly deteriorated" (1) to "strongly improved" (5).

Independent variables. We assessed the level of adoption of three major technologies that have been associated to MC systems: Computerized Numerical Control (CNC), Flexible Manufacturing Systems and their components (FMS), and Internet applications in sales and customer management (Internet). Even though $\mathrm{CNC}$ can be also considered part of FMS, we decided to keep those variables separate because of their importance and due to the fact that CNC adoption is often independent from FMS adoption (Johansen et al., 1995, for example, denote CNC adoption by the term "point automation" and FMS adoption by the term "islands of automation" to emphasize the independence between these two courses of action).

CNC adoption was assessed by two items ("Standalone/NC machines" and "CNC-DNC"), using the question, "Please indicate to what extent the operational activity is performed using the following technologies". Respondents used a five-point scale ranging from "no use" (1) to "high use" (5). FMS adoption was assessed by five items ("Robots", "Automated guided vehicles (AGVs)", "Automated storage-retrieval systems (AS/ RS)", "Flexible manufacturing/assembly systems - cells
(FMS/FAS/FMC)", and "Computer-aided inspection/ testing/tracking"), which are the typical components of FMS (Treywin, 1983; Goldhar and Lei, 1995; Mahmoodi, 2001). They were assessed by the same question and scale used to quantify $\mathrm{CNC}$ adoption. Finally, Internet adoption was assessed by three items ("Order processing and tracking", "Sales", and "Customer service and support (CRM)") representing the major aspects in manufacturing-customer relationship. Answers to the question, "Please indicate to what extent you use Internet to integrate the activities of the following processes along the supply chain" were given using a five-point scale, ranging from "no use" (1) to "high use" (5).

Factor analysis using principal components and Varimax rotation confirmed the scales convergent and discriminant validity (Table 4). The three factors had eigenvalues greater than 1 and accounted for 56 percent of the cumulative variance. Responses reliability within each factor was measured using Cronbach's alpha calculations. In all cases alpha results were larger than 0.55 , which is the threshold value for newly developed scales proposed by Nunally (1967). Three summated scales comprised of the average of the variable scores within each factor were used as independent variables in the regression models.

Control variables. Size can affect a unit's performance; large firms tend to have more resources to invest 
Table 4. Factor analysis results*.

\begin{tabular}{|c|c|c|c|}
\hline Variables & Factor 1 & Factor 2 & Factor 3 \\
\hline \multicolumn{4}{|l|}{ Internet } \\
\hline Internet sales & .8553 & .0973 & .0902 \\
\hline $\begin{array}{l}\text { Internet customer service and } \\
\text { support }(\mathrm{CRM})\end{array}$ & .8319 & .1756 & .0316 \\
\hline $\begin{array}{l}\text { Internet order processing and } \\
\text { tracking }\end{array}$ & .8043 & .1647 & -.0326 \\
\hline \multicolumn{4}{|l|}{ FMS } \\
\hline $\begin{array}{l}\text { Computer-aided inspection/ } \\
\text { testing/tracking }\end{array}$ & .2189 & .6795 & -.1080 \\
\hline $\begin{array}{l}\text { Flexible manufacturing/ } \\
\text { assembly systems-cells }\end{array}$ & .1472 & .6298 & -.1253 \\
\hline Robots & .0989 & .5931 & .2717 \\
\hline $\begin{array}{l}\text { Automated storage-retrieval } \\
\text { systems (AS/RS) }\end{array}$ & .0821 & .5588 & -.0909 \\
\hline $\begin{array}{l}\text { Automated guided vehicles } \\
(\mathrm{AGVs})\end{array}$ & .0144 & .5415 & .2036 \\
\hline \multicolumn{4}{|l|}{ CNC } \\
\hline CNC-DNC & -.0149 & .1648 & .8065 \\
\hline Stand-alone/NC machines & .0801 & -.1631 & .8029 \\
\hline Eigenvalue & 2.77 & 1.44 & 1.34 \\
\hline Percent of variance explained & 27.73 & 14.43 & 13.40 \\
\hline Cumulative percent & 27.73 & 42.16 & 55.56 \\
\hline Cronbach's alpha & .80 & .58 & .56 \\
\hline
\end{tabular}

* Main component extraction with Varimax rotation. Factor loadings greater than .40 are in bold.

in performance improvements (Tsai, 2001). Therefore, size was included as a control and was measured by the number of employees: "At the end of the last fiscal year, in your business unit you had employees in total". End user sales ("Please identify to what extent do you sell your products to end users: $\%$ of total sales") and market growth ("How would you describe the development of the total market of that product line that you serve? (1) declining rapidly, (2) declining, (3) stable, (4), growing, (5) growing rapidly") are two environmental factors that may affect manufacturer's focus on MC (Fitzgerald, 1995; Roberts, 2000). Finally, cellular manufacturing ("Please indicate to what extent your activity is organized in the following layout categories - indicate percentage of total volume: cellular layout___ \%") and multi-skilled labor ("How many of your production workers do you consider as being multi-skilled? $\%$ of total number of production workers") are factors having influence on MC ability (Dunphy and Bryant, 1996; Fliedner and Vokurka, 1997).

\section{Results}

Table 3 presented the means, standard deviations, and ANOVA between clusters, highlighting the significant differences between their market coverage and customer focus. It also showed that, except for the $F$-value in FMS adoption, there were no significant differences between clusters regarding dependent, independent, and control variables used in the regression models. Therefore, differences in regression coefficients between the two clusters could not be explained by variables other than market coverage and customer focus.

Table 5 presents the correlations between variables within each cluster. The low correlations allowed us to include all control variables in a single regression model (Carpenter and Fredrickson, 2001). However, since some correlations between independent variables appeared as significant, we tested their separate effects on various reduced models to assess multicollinearity effects on the results. Reduced models were comprised of all control variables and one independent variable. The only significant difference from the complete models in Table 6 was that the standardized coefficient for Internet in a reduced model 3.2 was slightly below the $10 \%$ threshold significance level $(p=.149)$. However, this result provided even stronger support to our conclusions and did not affect the complete models 1.2 and 4.2. Also, variance inflation factor (VIF) scores for all models were below the maximum tolerance of 10.0 (Mendenhall and Sincich, 1996: 357; Hair et al., 1998: 221), further suggesting that complete models could be used.

The research hypothesis was tested using hierarchical regression analysis. Regression analysis is a statistical analysis used to assess the strength of relationships between one dependent variable and several independent variables (Hair et al., 1998), i.e. the types of relationships anticipated in H1. Table 6 shows the results of the hierarchical regression analyses estimating the effects of CNC, FMS, and Internet adoption on MC, product customization ability, and labor productivity improvements in the two clusters. In each case, the first model includes only the control variables, and the second model adds the variables needed to test the research hypothesis.

Models 1.1 to 3.2 estimate the effects of control and independent variables on each of the three dependent variables in the narrow focus cluster (composed of 200 companies with "few markets" and "few customers"). Findings indicate that technology adoption did not have a significant effect on the MC ability of the narrowly focused manufacturers in our sample. The only significant relationships were the positive effect of end user sales on product customization ability $(p<.10)$ and the negative effect of Internet adoption on labor productivity $(p<.10)$.

Models 4.1 to 6.2 estimate the effects of control and independent variables on dependent variables in the broad focus cluster. This cluster is comprised of 115 manufacturers, which operated with "many markets" and "many 
Table 5. Bivariate correlations.

\begin{tabular}{|c|c|c|c|c|c|c|c|c|c|c|c|}
\hline \multicolumn{12}{|c|}{ Group 1: Narrow Market Coverage and Customer Focus $(n=200)$} \\
\hline Variable & 1 & 2 & 3 & 4 & 5 & 6 & 7 & 8 & 9 & 10 & 11 \\
\hline \multicolumn{12}{|l|}{ 1. Market coverage } \\
\hline 2. Customer focus & .06 & & & & & & & & & & \\
\hline $\begin{array}{l}\text { 3. Product customization } \\
\text { ability }\end{array}$ & -.03 & -.12 & & & & & & & & & \\
\hline 4. Labor productivity & .02 & .00 & .13 & & & & & & & & \\
\hline 5. $\mathrm{CNC}$ & .10 & -.07 & -.02 & -.09 & & & & & & & \\
\hline 6. FMS & .13 & -.03 & .04 & .05 & .10 & & & & & & \\
\hline 7. Internet & -.01 & .13 & .01 & -.11 & .03 & $.33 * * *$ & & & & & \\
\hline 8. Size & .04 & $-.15^{*}$ & .04 & .01 & .10 & $.27 * * *$ & .10 & & & & \\
\hline 9. End user sales & .04 & .02 & .12 & -.02 & -.06 & $-.27 * * *$ & -.12 & -.13 & & & \\
\hline 10. Market growth & -.03 & -.14 & .02 & .09 & .12 & .13 & .04 & .14 & -.04 & & \\
\hline 11. Cellular manufacturing & -.06 & -.11 & .00 & -.09 & -.02 & $.16^{*}$ & .12 & -.05 & -.10 & .03 & \\
\hline 12. Multi-skilled labor & .07 & .01 & .07 & -.03 & -.07 & .06 & .11 & $-.19 * *$ & .12 & -.03 & $.24 * * *$ \\
\hline \multicolumn{12}{|c|}{ Group 2: Broad Market Coverage and Customer Focus $(n=115)$} \\
\hline Variable & 1 & 2 & 3 & 4 & 5 & 6 & 7 & 8 & 9 & 10 & 11 \\
\hline \multicolumn{12}{|l|}{ 1. Market coverage } \\
\hline 2. Customer focus & -.03 & & & & & & & & & & \\
\hline $\begin{array}{l}\text { 3. Product customization } \\
\text { ability }\end{array}$ & $.27 * *$ & .10 & & & & & & & & & \\
\hline 4. Labor productivity & -.16 & .16 & -.14 & & & & & & & & \\
\hline 5. $\mathrm{CNC}$ & .11 & .11 & $.25^{* *}$ & .02 & & & & & & & \\
\hline 6. FMS & .01 & .11 & .08 & $.27 * *$ & -.07 & & & & & & \\
\hline 7. Internet & .13 & .13 & $.27 * *$ & .07 & .09 & $.36 * * *$ & & & & & \\
\hline 8. Size & -.18 & .10 & .07 & .11 & -.02 & $.22 *$ & -.04 & & & & \\
\hline 9. End user sales & .05 & -.10 & -.04 & $-.19^{*}$ & -.09 & -.12 & -.04 & $.19 *$ & & & \\
\hline 10. Market growth & .08 & .17 & -.13 & .14 & -.05 & $.20 *$ & .01 & -.06 & -.07 & & \\
\hline 11. Cellular manufacturing & .12 & .09 & .00 & -.04 & .14 & .14 & .06 & -.07 & -.06 & .04 & \\
\hline 12. Multi-skilled labor & .05 & -.10 & -.02 & -.12 & -.11 & -.09 & -.06 & -.13 & -.12 & -.11 & .07 \\
\hline
\end{tabular}

$* p<.05$ (two-tailed).

$* * p<.01$ (two-tailed).

$* * * p<.001$ (two-tailed)

customers". Despite the smaller cluster size, these models presented statistical significance. Regarding the control variables, size $(p<.10)$ was positively associated to MC improvement, and end user sales $(p<.05)$ was negatively associated to labor productivity and, as a consequence, to MC improvement. Those results were expected; size usually affects the operations performance, and relationship to end-users may reduce labor productivity due to the well-known trade-off between cost and customer service. Regarding the independent variables, the effects of technology adoption on MC, product customization, and labor productivity were mostly positive and significant. In model 4.2, the coefficients for CNC $(p<.05)$, FMS $(p<.10)$, and Internet $(p<.10)$ were positive and significant, indicating that technology adoption had a positive effect on the MC ability of broad market manufacturers. Models 5.2 and 6.2 explain why those relationships occurred:
$\mathrm{CNC}$ and Internet had a positive and significant $(p<.05)$ effect on product customization ability and a non-significant effect on labor productivity; FMS had a positive and significant $(p<.05)$ effect on labor productivity and a non-significant effect on product customization ability.

Our major interest was to compare model 1.2 (MC in Cluster 1) to model 4.2 (MC in Cluster 2). Hypothesis 1 states that technology adoption is more positively related to MC ability when the firm has broad market scope than when the firm has narrow market scope. As shown in Table 6, the effects of technology adoption on MC ability were more positive and significant in model 4.2 than in model 1.2. The results confirm H1. Even though the levels of performance and technology adoption were not significantly different between clusters, the predicted relationship between technology adoption and MC ability was only observed in the case of broad market firms. 
Table 6. Results of Hierarchical Regression Analysis*.

\begin{tabular}{|c|c|c|c|c|c|c|}
\hline \multirow{2}{*}{$\begin{array}{c}\text { Cluster 1: Narrow Focus }(n=200) \\
\text { Variable }\end{array}$} & \multicolumn{2}{|c|}{ Mass Customization } & \multicolumn{2}{|c|}{ Product Custom. Ability } & \multicolumn{2}{|c|}{ Labor Productivity } \\
\hline & 1.1 & 1.2 & 2.1 & 2.2 & 3.1 & 3.2 \\
\hline Size & .044 & .038 & .064 & .049 & -.010 & -.014 \\
\hline End user sales & .062 & .068 & $.122 * *$ & $.136^{* *}$ & -.032 & -.026 \\
\hline Market growth & .055 & .058 & .017 & .013 & .089 & .094 \\
\hline Cellular manufacturing & -.084 & -.087 & -.001 & -.009 & -.099 & -.102 \\
\hline Multi-skilled labor & .045 & .045 & .070 & .063 & -.006 & -.006 \\
\hline $\mathrm{CNC}$ & & -.084 & & -.020 & & -.108 \\
\hline FMS & & .093 & & .065 & & .106 \\
\hline Internet & & -.111 & & -.001 & & $-.130 * *$ \\
\hline$R^{2}$ & .017 & .037 & .023 & .026 & .018 & .047 \\
\hline Adjusted $R^{2}$ & -.009 & -.003 & -.003 & -.015 & -.008 & .007 \\
\hline$\Delta R^{2}$ & .017 & .020 & .023 & .004 & .018 & .029 \\
\hline$F$-change & .655 & 1.342 & .896 & .242 & .700 & 1.967 \\
\hline Cluster 2: Broad Focus $(n=115)$ & \multicolumn{2}{|c|}{ Mass Customization } & \multicolumn{2}{|c|}{ Product Custom. Ability } & \multicolumn{2}{|c|}{ Labor Productivity } \\
\hline Variable & 4.1 & 4.2 & 5.1 & 5.2 & 6.1 & 6.2 \\
\hline Size & $.163 * *$ & .127 & .070 & .080 & .144 & .084 \\
\hline End user sales & $-.190 * * *$ & -.136 & -.071 & -.036 & $-.233 * * *$ & $-.188 * *$ \\
\hline Market growth & .000 & -.016 & -.133 & -.116 & .120 & .079 \\
\hline Cellular manufacturing & -.007 & -.072 & .011 & -.038 & -.037 & -.073 \\
\hline Multi-skilled labor & -.126 & -.073 & -.037 & .016 & -.112 & -.096 \\
\hline $\mathrm{CNC}$ & & $.203 * * *$ & & $.226 * * *$ & & .023 \\
\hline FMS & & $.174 * *$ & & .014 & & $.223 * * *$ \\
\hline Internet & & $.183^{* *}$ & & $.251 * * *$ & & -.019 \\
\hline$R^{2}$ & .067 & .186 & .026 & .146 & .089 & .129 \\
\hline Adjusted $R^{2}$ & .024 & .125 & -.019 & .082 & .048 & .063 \\
\hline$\Delta R^{2}$ & .067 & .119 & .026 & .120 & .089 & .039 \\
\hline$F$-change & 1.561 & $5.181 * * * *$ & .581 & $4.972 * * * *$ & $2.139 * *$ & 1.600 \\
\hline
\end{tabular}

\section{Discussion}

We investigated the effects of technology adoption on the MC ability of manufacturing firms having broad and narrow market strategies. Research findings generated knowledge about two critical issues in the MC research: i) the impact of different technologies on the two MC dimensions of product customization and productivity and ii) the influence of market scope on the relationship between technology adoption and MC.

\subsection{Technology impact on mass customiza- tion}

Research results indicate that CNC, FMS, and Internet had a positive and significant impact on MC in broad market firms which may be derived from their ability to improve one MC dimension at no expense to the other. However, results indicated that different technologies were associated to improvement in different mass cus- tomization dimensions. On one hand, $\mathrm{CNC}$ and Internet had a positive impact on product customization ability, at no expense to labor productivity. On the other hand, FMS had a positive impact on labor productivity, at no expense to product customization ability. Our results on FMS are consistent with Jaikumar's (1986) early study of adoption of this technology in the U.S., which suggested that manufacturers used FMS for productivity more than variety production.

This finding is particularly relevant for its contrast to traditional and modern trade-off theories. Technologies neither appeared to have an uneven effect on MC dimensions (i.e., improving one dimension while reducing the other, as suggested in traditional trade-off studies such as Skinner, 1969), nor they brought improvements across-the-board (i.e., raising performance in both dimensions simultaneously, as suggested in World-Class Manufacturing studies such as Schonberger, 1986). Their actual effects appeared 
to be more complex. First, even technologies such as CNC and FMS, which at first would appear to have a similar role in manufacturing, had different effects on productivity and customization ability. Second, as we mentioned above, the effects of technologies in one dimension did not appear to cause either an improvement or a reduction in the other. Third and most significantly, the positive impact of technologies on MC dimensions occurred in only one of the clusters, suggesting that other variables such as market strategy might have a significant influence on the economic returns from technology investments. This last aspect leads to our second discussion point.

\subsection{Moderating effect of market scope}

Results provided empirical evidence to the role of market scope on technology's impact in MC. There was a clear distinction on the relationship between technology adoption and MC between broad and narrow market firms. In broad market firms, technology adoption was positively and significantly related to improvement in MC capabilities. In narrow market firms, however, there seemed to be no relationship between technology adoption and MC.

The findings relating to broad market firms mostly conform to the literature. CNC, FMS, and Internet have been identified as major enablers to MC (McDermott et al., 1997; da Silveira et al., 2001; Zipkin, 2001). In addition, authors such as Zipkin (2001) and Duray (2002) emphasized the need for MC strategies to be developed in high-volume, mass-market contexts. Our results provide empirical support to those claims.

The findings relating to narrow market firms, on the other hand, are more puzzling. Results indicated no significant relationship between MC and technology adoption in the narrow cluster, even though there were no significant differences in the means of dependent and independent variables between the two clusters. We may suggest some explanations for the role of technology in narrow market firms. First, since FMS seemed to be less adopted than in the broad market firms, its relevance in enabling MC might be simply not envisioned by those firms. FMS could be more likely viewed as a means to attain higher productivity and quality levels, as proposed in Jaikumar (1986), and Norman and Thisse (1999). However when testing the relationship between FMS and labor productivity in model 3.2, no significant positive correlation was detected. Furthermore, CNC and Internet seemed to be equally adopted in narrow market firms, but could have different purposes. For example, CNC might be used for improving product quality (Levary 1994; Bullen, 1997) rather than customization; Internet might be used for improving customer service (Walsh and Godfrey, 2000). Finally, technologies could have been adopted for similar purposes as in broad market firms, but their contribution to MC ability might not have been realized due to lack of opportunities or demand for MC (Zipkin, 2001).

\section{Conclusion}

This study investigated the relationship between market scope, technology adoption, and MC. We built a hierarchical regression model to test the effect of three major technologies on the MC ability of manufacturing firms with narrow and broad market strategies. We selected three of the major technologies that have been associated to $\mathrm{MC}$ in the literature: i) CNC; ii) FMS in fabrication; and iii) Internet in sales and customer relationship management. The MC ability construct in our work corresponded to the interaction between the two performance dimensions involved in the MC trade-off: labor productivity and product customization ability. Results mainly indicated that $\mathrm{i}$ ) different technologies were associated to improvement in different MC dimensions; and ii) market scope had a moderating effect on the relationship between technology and MC.

Our study may show itself limited in two ways. First, we obtained our data from an existing database (IMSS) rather than a study-focused survey. However using the IMSS database is justified by the gain in sample reliability and scale it promotes. Second, our analysis is limited to manufacturers of fabricated metal products, machinery, and equipment. The IMSS database is focused on such single sector to improve the validity of research findings and enable cross-national comparisons. Therefore, caution must be taken in generalizing results to other industries.

The results present major contributions to the research on MC. They provide empirical support to the moderating effect of market strategy on the relationship between technology and MC. Our research aimed at reducing the empirical gap in $\mathrm{MC}$ research pointed out by $\mathrm{Tu}$ et al. (2001). In addition, we clarify the distinctive role of three major technologies in the MC dimensions of productivity and product customization. For that matter, we followed Åhlström and Westbrook (1999), who highlighted the need for more research on the role of manufacturing and information technologies in MC.

The research implications of our findings are also twofold. First, the empirical analysis of technology-performance relationships in MC systems must include market and operations strategy variables. Our study provides additional evidence that returns from technology and operations improvements are influenced by strategic factors such as market scope, industrial competitiveness, and competitive priorities. The insertion of such variables in empirical models will often enrich the validity and relevance of research results. The second implication concerns the multidimensional, trade-off nature of the MC concept. 
To implement such a concept in practice, a firm must simultaneously consider the two performance dimensions of product customization and productivity. Alternative variables such as product variety or production cost could be used; however, it would seem a mistake to attempt at measuring $\mathrm{MC}$ abilities using unidimensional variables that fail to address the trade-off at the heart of MC.

The major practical implication derived from our research is that managers should relate the capabilities provided by advanced technologies with the market and operations strategy of the firm. In our study, the first group of firms might not be realizing the benefits from technology adoption because of their narrow market fo- cus. For example, customization capabilities provided by CNCs might not be fully explored due to low demand for personalized products; productivity improvements from FMS adoption could result in excess capacity in the absence of opportunities to market the product catalogue.

\section{Acknowledgment}

Dr. da Silveira's research is supported by the Natural Sciences and Engineering Research Council of Canada - Discovery Grant \#283134-04. Dr. Fogliatto's research is supported by CAPES (grant \#0293-05-9) and CNPq (grant \#301433/2005-4).

\section{Bibliographical References}

ÅHLSTRÖM, P.; WESTBROOK, R. Implications of mass customization for operations management: an exploratory survey. International Journal of Operations and Production Management, v. 19, n. 3, p. 262-274, 1999.

BOYNTON, A. C.; VICTOR, B.; PINE II, B. J. New competitive strategies: challenges to organizations and information technology. IBM Systems Journal, v. 32, n. 1, p. 40-64, 1993.

BROEKHUIZEN, T. L. J.; ALSEM, K. J. Success factors for mass customization: a conceptual model. Journal of Market-Focused Management, v. 5, n. 4, p. 309-330, 2002.

BULLEN, G. N. The mechanization/automation of major aircraft assembly tools. Production and Inventory Management Journal, v. 38, n. 3, p. 84-87, 1997.

BYRD, T. A. Information technology, core competencies, and sustained competitive advantage. Information Resources Management Journal, v. 14, n. 2, p. 27-36, 2001.

CAGLIANO, R.; SPINA, G. Advanced manufacturing technologies and strategically flexible production. Journal of Operations Management, v. 18, n. 2, p. 169-190, 2000.

CARPENTER, M. A.; FREDRICKSON, J. W. Top management teams, global strategic posture, and the moderating role of uncertainty. Academy of Management Journal, v. 44, n. 3, p. 533-545, 2001.

CHAN, F. Y.; CHEUNG, W. K. A knowledge-based recommender system for customized online shopping. In: WORLD CONGRESS ON MASS CUSTOMIZATION AND PERSONALIZATION, October, 2001, Hong Kong. Proceedings... 2001. CD-ROM.

CROSBY, L. A.; JOHNSON, S. L. The globalization of relationship marketing. Marketing Management, v. 11, n. 2, 10-11, 2002.
DA SILVEIRA, G.; BORENSTEIN, D.; FOGLIATTO, F. S. Mass customization: literature review and research directions. International Journal of Production Economics, v. 72, n. 1, p. 1-13, 2001.

DAVIS, S. Future Perfect, Addison-Wesley, Reading, MA, 1987.

DILLMAN, D. A. Mail and Telephone Surveys: The Total Design Method, Wiley, New York, 1978.

DUNPHY, D.; BRYANT, B. Teams: panaceas or prescriptions for improved performance. Human Relations, v. 49, n. 5, p. 677-699, 1996.

DURAY, R. Mass customization origins: mass or custom manufacturing. International Journal of Operations and Production Management, v. 22, n. 6, p. 314-328, 2002.

DURAY,R.;WARD,P.T.;BERRY,W.L.;MILLIGAN, G. W. Approaches to mass customization: configurations and empirical validation. Journal of Operations Management, v. 18, n. 6, p. 605-625, 2000.

EASTWOOD, M. A. Implementing mass customization. Computers in Industry, v. 30, n. 3, p. 171-174, 1996.

FEITZINGER, E.; LEE, H. Mass customization at HewlettPackard: the power of postponement. Harvard Business Review, v. 75, n. 1, p. 116-121, 1997.

FIORE, A. M.; LEE, S.-E.; KUNZ, G. Individual differences, motivations, and willingness to use a mass customization option for fashion products. European Journal of Marketing, v. 38, n. 7, p. 835-849, 2004.

FITZGERALD, B. Mass customization - at a profit. World Class Design to Manufacture, v. 2, n. 1, p. 43-46, 1995.

FLIEDNER, G.; VOKURKA, R. J. Agility: competitive weapon of the 1990's and beyond? Production and In- 
ventory Management Journal, v. 38, n. 3, p. 19-24, 1997.

FOGLIATTO, F. S.; DA SILVEIRA, G.; ROYER, R. A. Flexibility-driven index for measuring mass customization feasibility on industrialized products. International Journal of Production Research, v. 41, n. 8, p. 1811-1829, 2003.

FROHLICH, M. T.; WESTBROOK, R. Arcs of integration: an international study of supply chain strategies. Journal of Operations Management, v. 19, n. 2, p. 185-200, 2001.

FÜRST, K.; SCHMIDT, T. Turbulent markets need flexible supply chain communication. Production Planning and Control, v. 12, n. 5, p. 525-533, 2001.

GOLDHAR, J. D.; LEI, D. Variety is free: manufacturing in the twenty-first century. Academy of Management Executive, v. 9, n. 4, p. 73-86, 1995.

GROSS, J. Individualization and personalization are characteristics of art - applied now as art customization. WORLD CONGRESS ON MASS CUSTOMIZATION AND PERSONALIZATION, October, 2001, Hong Kong. Proceedings... 2001. CD-ROM.

HAIR, J. F. Jr.; ANDERSON, R. E.; TATHAM, R. L., BLACK, W. C. Multivariate Data Analysis with Readings, 5. ed., Prentice Hall, Upper Saddle River, NJ, 1998.

HART, C. W. Made to order. Marketing Management, v. 5, n. 2, p. 10-23, 1996.

HART, C. W. Mass customization: conceptual underpinnings, opportunities and limits. International Journal of Service Industry Management, v. 6, n. 2, p. 36-45, 1995.

JAIKUMAR, R. Postindustrial manufacturing. Harvard Business Review, v. 64, n. 6, p. 69-76, 1986.

JIAO, J.; TSENG, M. M. Understanding product family for mass customization by developing commonality indices. Journal of Engineering Design, v. 11, n. 3, p. 225-243, 2000.

JINA, J.; BHATTACHARYA, A. K.; WALTON, A. D. Applying lean principles for high product variety and low volumes: some issues and propositions. Logistics Information Management, v. 10, n. 1, p. 5-13, 1997.

JOHANSEN, J.; KARMARKAR, U. S.; NANDA, D., Seidmann, A. Computer integrated manufacturing: empirical implications for industrial information systems. Journal of Management Information Systems, v. 12, n. 2, p. 59-70, 1995.

KAGAN, A.; POST, G.; NOEL, C. M. Selling the Web: Web features used by retailers. Journal of Applied Business Research, v. 16, n. 1, p. 15-25, 2000.
KARNES, C. L.; KARNES, L. P. Ross controls: a case study in mass customization. Production and Inventory Management Journal, v. 41, n. 3, p. 1-4, 2000.

KELTNER, B.;FINEGOLD, D.; MASON, G.;WAGNER, K. Market segmentation strategies and service sector productivity. California Management Review, v. 41, n. 4, p. 81-102, 1999.

KOTHA, S. From mass production to mass customization: the case of the National Industry Bicycle Company of Japan. European Management Journal, v. 14, n. 5, p. 442-450, 1996.

KOTHA, S. Mass customization: implementing the emerging paradigm for competitive advantage. Strategic Management Journal, v. 16, p. 21-42, 1995.

LAU, R. S. M. Strategic flexibility: a new reality of WorldClass manufacturing. S.A.M. Advanced Management Journal, v. 61, n. 2, p. 11-15, 1996.

LEVARY, R. R. Programmable automation in manufacturing systems. Industrial Management, v. 36, n. 3, p. 21-25, 1994.

LIECHTY, J.; RAMASWAMY, V.; COHEN, S. H. Choice menus for mass customization: an experimental approach for analyzing customer demand with an application to a Web-based information service. Journal of Marketing Research, v. 38, n. 2, p. 183-196, 2001.

MAHMOODI, F. Analysis of automated guided vehicle configurations in flexible manufacturing systems. International Journal of Production Research, v. 39, n. 18, p. 4239-4260, 2001.

MANN, D. L.; DOMB, E. Using TRIZ to overcome mass customization contradictions. WORLD CONGRESS ON MASS CUSTOMIZATION AND PERSONALIZATION, October, 2001, Hong Kong. Proceedings... 2001. CD-ROM.

MCDERMOTT, C. M.; GREIS, N. P.; FISCHER, W. A. The diminishing utility of the product/process matrix: a study of the US power tool industry. International Journal of Operations and Production Management, v. 17, n. 1-2, p. 65-84, 1997.

MCMAINS, S. Layered manufacturing technologies. Communications of the ACM, v. 48, n. 6, p. 50-56, 2005.

MENDENHALL, W.; SINCICH, T. A Second Course in Statistics: Regression Analysis, 5. ed., Prentice Hall, Upper Saddle River, NJ, 1996.

NORMAN, G.; THISSE, J. F. Technology choice and market structure: strategic aspects of flexible manufacturing. The Journal of Industrial Economics, v. 47, n. 3, p. 345-372, 1999.

NUNALlY, J. C. Psychometric Theory, 2. ed., McGrawHill, New York, 1967. 
PINE II, B. J. Mass customizing products and services. Planning Review, v. 21, n. 4, p. 6-13, 1993.

PINE II, B. J.; PEPPERS, D.; ROGERS, M. Do you want to keep your customers forever? Harvard Business Review, v. 73, n. 2, p. 103-113, 1995.

PRABHAKER, P. Integrated marketing-manufacturing strategies. The Journal of Business and Industrial Marketing, v. 16, n. 2, p. 113-128, 2001.

PUNJ, G.; STEWART, D. W. Cluster analysis in marketing research: review and suggestions for application. Journal of Marketing Research, v. 20, n. 2, p. 134-148, 1983.

QUINTELLA, H. M.; DANTAS, M. A. M.; CONFORT, B. Competitividade, gestão estratégica e práticas de liderança. Relatórios de Pesquisa em Engenharia de Produção, v. 5, 2005a.

QUINTELLA, H. M.; PAIM, D. J. B.; PESTANA, C. Aplicação da tecnologia da informação na customização em massa no setor de telecomunicações. Relatórios de Pesquisa em Engenharia de Produção, v. 5, 2005 b.

QUINTELLA, H. M.; SILVA, L. R. P. TI e competitividade no varejo. Relatórios de Pesquisa em Engenharia de Produção, v. 3, 2003.

RENCHER, A. C. Methods of Multivariate Analysis. New York: John Wiley, 1995.

ROBERTS, J. H. Developing new rules for new markets. Journal of the Academy of Marketing Science, v. 28, n. 1, p. 31-44, 2000.

SCHONBERGER, R. World class manufacturing. New York: Free Press, 1986.

SKINNER, W. Manufacturing: missing link in corporate strategy. Harvard Business Review, v. 47, n. 3, p. 139-145, 1969.

TAYLOR, S.; LYON, P. Paradigm lost: the rise and fall of McDonaldization. International Journal of Contemporary Hospitality Management, v. 7, n. 2, 3, p. 64-68, 1995.
TREYWIN, E. T. Quality control within a flexible manufacturing system. EUROPEAN CONFERENCES ON AUTOMATED MANUFACTURING, 2., 1983, Birmingham, UK. Proceedings... 1983 p. 99-108.

TSAI, W. Knowledge transfer in intraorganizational networks: effects of network position and absorptive capacity on business unit innovation and performance. Academy of Management Journal, v. 44, n. 5, p. 996-1004, 2001.

TU, Q.; VONDEREMBSE, M. A.; RAGU-NATHAN, T. S. The impact of time-based manufacturing practices on mass customization and value to customer. Journal of Operations Management, v. 19, n. 2, p. 201-217, 2001.

TU, Q.; VONDEREMBSE, M. A.; RAGU-NATHAN, T. S.; RAGU-NATHAN, B. Measuring modularity-based manufacturing practices and their impact on mass customization capability: a customer-driven perspective. Decision Sciences, v. 35, n. 2, p. 147-168, 2004.

VOSS, C.; BLACKMON, K. Differences in manufacturing strategy decisions between Japanese and Western manufacturing plants: the role of strategic time orientation. Journal of Operations Management, v. 16, n. 2-3, p. 147-158, 1998.

WALSH, J.; GODFREY, S. The Internet: a new era in customer service. European Management Journal, v. 18, n. 1 , p. $85-92,2000$.

WESTBROOK, R.; WILLIAMSON, P. J. Mass customization: Japan's new frontier. European Management Journal, v. 11, n. 1, p. 38-45, 1993.

XIAO, T.; QIAO, G.; Dong, J. Implementing strategy and key technologies of mass customization in automotive manufacturing. WORLD CONGRESS ON MASS CUSTOMIZATION AND PERSONALIZATION, October, 2001, Hong Kong. Proceedings... 2001. CD-ROM.

ZIPKIN, P. The limits of mass customization. MIT Sloan Management Review, v. 42, n. 3, 81-87, 2001. 


\section{EFEITOS DA ADOÇÃO DA TECNOLOGIA SOBRE A CAPACIDADE PARA CUSTOMIZAÇÃO EM MASSA EM EMPRESAS COM ESCOPOS DE MERCADO AMPLOS E FOCALIZADOS}

\section{Resumo}

Apesar do número crescente de estudos sobre a Customização em Massa (CM) enfocando tanto aspectos teóricos quanto práticos desta estratégia, duas lacunas persistem nas pesquisas sobre o assunto. A primeira diz respeito à ausência de estudos empíricos que testem a relação, prevista na teoria, entre aspectos estratégicos, técnicos e de desempenho da CM (Tu et al., 2001). A segunda lacuna está relacionada à compreensão limitada acerca do papel da tecnologia, em particular da tecnologia de informação, nos sistemas de CM (Åhlström and Westbrook, 1999). Este artigo investiga os efeitos da adoção da tecnologia sobre a capacidade para CM de 315 produtores de bens de metal, máquinas e equipamentos que atuam em mercados amplos ou focalizados. Os resultam indicam que diferentes tecnologias possuem efeitos distintos sobre as dimensões de variedade e produtividade da CM, e que tais efeitos são determinados pelo escopo de mercado das empresas.

Palavras-chave: customização em massa, tecnologia, interface marketing/operações. 